\title{
CORRESPONDENCE.
}

\author{
PIPES IN COAST SANDSTONES.
}

SrR,-It is interesting to note in connection with Professor Day's paper on "Pipes in the Coast Sandstone of Syria", published in your September number, that pipes agreeing in a remarkable manner with those described by him are present in a Pleistocene sandstone on the north shore of Barnstaple Bay in Devonshire, between Saunton and Downend. Here a calcareous sandstone overlies the well known $15 \mathrm{ft}$. raised beach and is unconformable to the Pilton Beds of the Upper Devonian. This sandstone, which is waterdeposited at the base but aeolian above, contains many vertical pipes which are apparently identical with those in the Syrian sandstone. The only different feature seems to be that, as the sea has excavated a number of small caves along the unconformable junction between the sandstone and the Pilton Beds, every pipe which has pierced the roof of a cave forms an open chimney through which it is possible to climb.

These Devonshire pipes do not seem to be as well known as they deserve to be, although they have been described in detail in various papers published many years ago in the Transactions of the Devonshire Association, notably by Mr. W. Pengelly, F.R.S., and Mr. J. G. Hamling. As far as I can remember, the conclusion arrived at by these authors was that the pipes were caused by solution, but, like Professor Day, they also found the general regularity and smoothness of the walls difficult to explain by this theory alone.

I hope that Professor Day's communication will have the result of bringing these remarkable Devonshire pipes out of their obscurity.

Masuid-i-Sulaiman,

N. L. Falcon.

South Persia.

18th October, 1928.

\section{BACK NUMBERS OF THE GEOLOGICAL MAGAZINE.}

SrR, - The Library of the University of Witwatersrand has lost its copy of the Geological Magazine for January, 1926, and January, 1927. Both numbers are out of print, and Mr. S. B. Asher, the Librarian, has asked me if I could help him in replacing these copies. If any readers of the MAGazine should be able to spare these numbers it would be very helpful if they would send them either to me or forward them direct to Mr. S. B. Asher, Seymour Memorial Tibrary, Kerk Street, Johannesburg.

Yours faithfully,

J. W. GREGORY. 